Crop Breeding and Applied Biotechnology S2: 75-86, 2012

Brazilian Society of Plant Breeding. Printed in Brazil

\title{
ARTICLE
}

\section{Genetic resources: the basis for sustainable and competitive plant breeding}

Luciano Lourenço Nass ${ }^{1}$, Mário Sérgio Sigrist ${ }^{2}$, Cláudia Silva da Costa Ribeiro ${ }^{3}$ and Francisco José Becker Reifschneider ${ }^{1,3}$

Received 15 September 2012

Accepted 03 October 2012

\begin{abstract}
Plant genetic resources are the fuel for breeding, which in the search for higher yield and adapted genotypes, manipulates genes in order to meet the needs of farmers, and especially, of the current market. However, the use of accessions available in germplasm banks is low. Topics discussed in this paper emphasize the importance of plant genetic resources, and warn about problems related to genetic vulnerability; also, they discuss about aspects of costs involved in conservation and suggest recommendations for strengthening the area in Brazil.
\end{abstract}

Key words: Agrobiodiversity, germplasm, conservation, sustainability, cost/benefit.

\section{INTRODUCTION}

\section{The importance of agrobiodiversity, an unexplored treasure}

Agriculture and biodiversity are intimately linked to each other. Biodiversity in agriculture is essential for human development. Agricultural biodiversity, or agrobiodiversity, is a generic term which basically includes all components of biological diversity (plants, animals, microorganisms) that are important for food and agriculture itself, as well as all components of ecological biodiversity that make up agroecosystems. The importance of agricultural biodiversity is evident, since it supplies food, wood, fiber, oil, medicine, and fuel. Furthermore, agrobiodiversity contributes to ecosystem services, being the conservation of water and soil the most known, as well as pollination.

The beginning of agriculture 10,000 years ago is undoubtedly one of the major events in the history of human life on Earth. Approximately 300,000 species of plants have been described, of which 3,000 have been used by humans for food. Currently, around 300 species are used, and out of these, only 15 are responsible for $90 \%$ of all human food. The 15 most used species are rice, wheat, corn, sorghum, barley, sugarcane, beet, potato, sweet potato, cassava, common bean, soybean, peanut, coconut, and banana (Goodman 1990). Together, rice, potato, corn and wheat, represent $60 \%$ of this total and are the staples of human consumption.

Brazil, as a megadiverse country, has extensive economic opportunity for the development of new food, fiber, drugs products; these unique opportunities also come accompanied by greater responsibility (Silva et al. 2011) to national and international society. The importance and the economic potential of this heritage for current and future Brazilian generations are monumental. For a significant portion of the population, agricultural biodiversity is the primary income source. In 2010, Brazil's agricultural gross domestic product (agricultural GDP) reached US\$ 821 billion, a total GDP of US\$3.7 trillion (http://www.cepea.esalq.usp.br/pib/); and millions of Brazilians rely on jobs related to agriculture. Historically, Brazil's agriculture has been one of the primary engines of economic growth. In 2010, the three main export items were soybean, iron ore and oil. Besides, coffee and meats were also among the most important agricultural export products.

Agriculture, when properly carried out, produces a range of environmental services and contributes significantly to the conservation and use of biodiversity. At the same time, agriculture can generate negative impacts to this same biodiversity, by the expansion of the agricultural frontier, the misuse of available technologies, or simply by greed, which is not controlled by the political system in which

\footnotetext{
1 Empresa Brasileira de Pesquisa Agropecuária (Embrapa), Secretaria de Relações Internacionais, 70.770-901, Brasília, DF, Brazil. *E-mail: Luciano.Nass@embrapa.br

${ }^{2}$ DuPont Pioneer - Pesquisa Soja, Rodovia DF 250, km 20, 73.301-970, Brasília, DF, Brazil

3 Embrapa Hortaliças, Rodovia Brasília/Anápolis BR 060, km 09, 70.359-970, Gama, DF, Brazil
} 
we live. This loss of diversity is a concern, since it puts at risk the agriculture and ecosystem services provided by it.

Brazil is the leading country among the megadiverse countries, holding in its territory an estimate of $13 \%$ of all species on the planet. Over $20 \%$ of the world flora, in a total of approximately 55,000 described species, are found in Brazil. Despite having the largest biodiversity on the planet, with a huge range of native species, Brazilian agriculture is highly dependent on exotic species ${ }^{4}$, both from the Americas and from other continents.

Brazil's agriculture is based, among others, on: sugar cane, from New Guinea; coffee, from Ethiopia; rice, from the Asian continent; soybeans and oranges, from China; corn, from Mexico; wheat, from Minor Asia. Several native species are important for human consumption with regional and local importance, such as cassava, pineapple, peanuts, cocoa, cashew, cupuaçu, passion fruit, guaraná, among others. Native forage species also contribute to the support of a good part of the livestock sector in Brazil (MMA 2011). Livestock depends on cattle from India and forage grasses brought originally from Africa. Fish farming depends on tilapia, from Eastern Africa, and carp, brought from China; moreover, apiculture and pollination of major crops are based on Africanized bees. However, this is not a Brazilian weakness, since the dependence of exotic genetic resources is a global phenomenon.

Em que se declara parte da fertilidade da terra de São Vicente. Nestas capitanias de São Vicente e Santo Amaro são os ares frios e temperados, como na Espanha, cuja terra é mui sadia e de frescas e delgadas águas, em as quais se dá o açúcar muito bem, e se dá trigo e cevada, do que se não usa na terra por os mantimentos dela serem muito bons e facilíssimos de granjear, de que os moradores são mui abastados e de muito pescado e marisco, onde se dão tamanhas ostras que têm a casca maior que um palmo, e algumas muito façanhosas... e criam-se aqui tantos porcos e tamanhos, que os esfolam para fazerem botas e couros de cadeiras, o que acham os moradores destas capitanias mais proveitosos e melhor que de couro das vacas, de que nestas capitanias há muita quantidade por se na terra darem melhor quê na Espanha, onde as carnes são muito gordas e gostosas, e fazem vantagem às das outras capitanias, por a terra ser mais fria. Dão-se nesta terra todas as frutas de espinho que tem Espanha...dão-se nestas capitanias uvas, figos, romãs, maçãs e marmelos, em muita quantidade, e também há já nesta terra algumas oliveiras, que dão fruto, e muitas rosas, e os marmelos... (Sousa 1879) (bold by authors).

\footnotetext{
4 An excellent example of this dependency is a text from the beginning of Brazilian colonization, below, written in 1587 (in bold, exotic species). In general, adapted to a modern English, the passage affirms that in the Captaincies of São Vicente and Santo Amaro, which today correspond to the territory of Macaé (RJ), Caraguatatuba (SP), Bertioga (SP) and Cananéia/Ilha do Mel (PR), the soil was fertile and it was abundant in water. In these Captaincies, sugarcane, wheat and barley were cultivated. Moreover, grapes were grown for wine production, as well as figs, pomegranates, apples and quinces. There are also records of fruiting olive trees.
}

Brazilian agriculture would never have reached today's stage without a systematic and growing import of these genetic resources for food, oil, fiber and energy. There are many good examples of this rich history (Reifschneider et al. 2010): it is noteworthy the introduction of cattle in Brazil, and the germplasm introduction and adaptation gardens of the $16^{\text {th }}$ century and beyond, exemplified by the Quinta do Tanque, demonstrating that the concern with agrobiodiversity in Brazil is historic!

\section{The "Quinta do Tanque" \\ The Quinta do Tanque, located in Salvador, Bahia, is considered one of the most important civilian monuments of Brazil. Its history begins in 1555, when the Jesuits built a cottage for the college of Bahia. A Quinta, measuring about two acres, had large gardens and a dam, or a tank. There, the Jesuits cultivated fruits and vegetables in an orchard irrigated by springs and precious water reservoirs, which is the origin of the name Quinta do Tanque. At the Quinta, plants from Europe, Asia and America were also cultivated. Later, the Quinta also served as experimental garden, in which species from all over the world were tested and selected. The cultivation of cinnamon in Brazil started at the Quinta, and cocoa started to be grown in Bahia (which was previously grown in Maranhão) by intervention of the Jesuits (Reifschneider et al. 2010).}

\section{The genetic vulnerability of agriculture nowadays and the successful use of native and exotic germplasm}

The use of 15 species that represents $90 \%$ of all human food makes clear the narrow basis on which we depend. A limited number of species that we use for our livelihood presents a huge concern about the genetic vulnerability of agriculture; a concern that once belonged to researchers, but which today permeates society. Despite the conservation of a vast amount of genetic variability in germplasm collections or banks, the economically important crops continue becoming more uniform. Thus, despite all the efforts made in the establishment of germplasm banks in the international arena, this was not enough to make the world agriculture less vulnerable to diseases and pests. The existence of this vulnerability is due to the use of uniform genotypes in extensive farming areas, and there are many examples well-studied examples of problems arising from such genetic uniformity. The disaster involving the use of potato clones susceptible to the fungus Phytophthora infestans in Ireland, the ruin of the grapevines caused by an insect parasite that feed on root of grapevines (Phylloxera) observed in France, and the use of corn hybrids with only one source of male-sterility susceptible to Helminthosporium maydis race $\mathrm{T}$ fungus are classic examples of genetic vulnerability. 
Nevertheless, there are many examples of successful use of native and exotic germplasm to support the development of national agriculture. The research in plant breeding and genetic resources is one of the most relevant innovation activities for the country, having produced results that have contributed significantly to the main qualitative and quantitative gains achieved by Brazilian agriculture - and Brazilian development - over the past decades. Plant breeding in Brazil is among the best in the world, with significant contributions, highlighting the well-trained human resources and the development of a large diversity of plants adapted to tropical conditions (Queiroz and Lopes 2007). Thus, it is important to mention the tropicalization of soybean, which allowed its cultivation in low latitude regions; the development of numerous varieties of cassava and beans with distinctive traits, including resistance to several pathogens; and the new cultivars of Capsicum peppers and peanuts (Arachis) for forage.

All this work aiming at the sustainable use of germplasm is based on the existence of collections or germplasm banks, used by the present generation and maintained for the future generations, and properly characterized so they can be effectively used in plant breeding. The availability of germplasm is of fundamental importance for the improvement of any species. Thus, every breeding program depends, ultimately, on genetic resources from germplasm banks or from those that are in use by farmers. Nass (2001) discussed in details the use of plant genetic resources for breeding.

\section{The importance of plant genetic resources}

Plant genetic resources (PGR) are the basis of food security and global energy. It is essential that these resources are properly preserved and characterized for the current and future demand, since they serve as raw material for plant breeding. Given their importance, it is expected that issues related to PGR are discussed frequently in various media in order to encourage debate in society. The degree of importance that society gives to certain subjects can be estimated, for example, through field surveys using structured questionnaires. However, a research of this kind has a high cost to obtain acceptable margins of error. Alternatively, the degree of exposure of a particular subject in the media can be used as a proxy for its significance to society. This latter approach was used here to illustrate the attention given to PGR by scientific journals. We evaluated papers published by five scientific journals of wide circulation nationally and internationally: $\mathrm{PAB}$ (Pesquisa Agropecuária Brasileira), CBAB (Crop Breeding and Applied Biotechnology), Horticultura Brasileira, Crop Science and HortScience. All articles published from January 2008 to the most recent volume were evaluated, regardless of the section in which the articles were allocated, making up a total of 4,777 papers analyzed. For each volume, the total number of published papers and the number of papers related to PGR were counted and classified by scanning the titles of articles, seeking for keywords such as germplasm, accession and pre-breeding. Abstracts were read in case of doubt. Articles related to PGR were then divided into three categories in order to identify the main objective of the study: conservation methods, evaluation/characterization and use in breeding. Manuscripts involving tissue culture, collection techniques, or improved cryopreservation protocols used in germplasm banks were classified as conservation methods. In turn, articles included in the category evaluation/characterization presented as objectives the characterization and evaluation of collections or sets of materials using molecular markers or agromorphological descriptors, and also the evaluation of genotypes regarding biotic and abiotic stresses. Finally, examples of manuscripts in the category use in breeding involved the use of native or exotic germplasm to develop populations and lines from backcrossing programs.

In general, there was a variation in the quantity of articles associated to PGR in relation to the journals. However, when the same journal was analyzed over the years, the number of articles related to genetic resources remained almost stable (Figure 1). These results suggest that, given the time horizon considered, there were no major changes related to the importance given to the subject PGR. Nevertheless, the results reflect the differences of the proposed objectives for each journal, which may be more focused on genetics and conservation or on the management and cultivation of crops. In absolute terms, the international journals evaluated showed a greater amount of published articles on genetic resources. In part, this happens due to the fact that these journals have specific sections for PGR in each volume, which indicates that the importance of this subject is consolidated in such journals. However, the evaluation of the importance given to the topic brings biased results in favor of international journals, as they also showed higher total number of papers. Thus, it is necessary to evaluate the importance given in relative terms (Figure 2). In this case, $\mathrm{CBAB}$ had the highest proportion of articles related to the topic, around $30 \%$, followed by international journals, with approximately $20 \%$ each.

Considering only those papers which discussed genetic resources, it was verified that the majority aimed at the evaluation or characterization of the genetic diversity of germplasm, followed by the use of the PGR in breeding, and finally, the development of methods and techniques of conservation (Figure 3). In general, this ranking of objectives remained consistent, both over the five years of evaluation as well as in relative terms within each journal (Figure 4). 


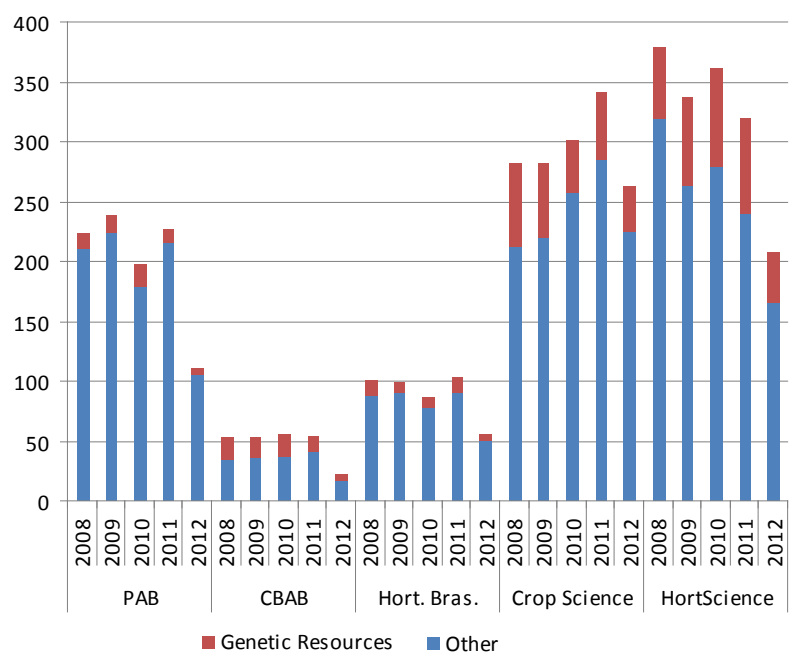

Figure 1. Amount of articles regarding plant genetic resources in relation to the total number of papers published according to the journal and year.

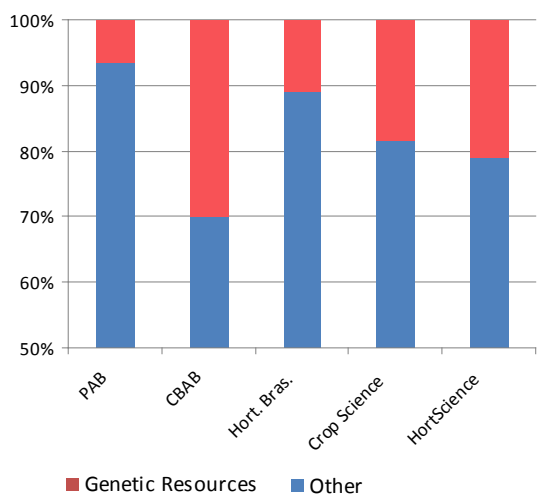

Figure 2. Percentages of articles related to plant genetic resources by journal, grouping all the years evaluated.

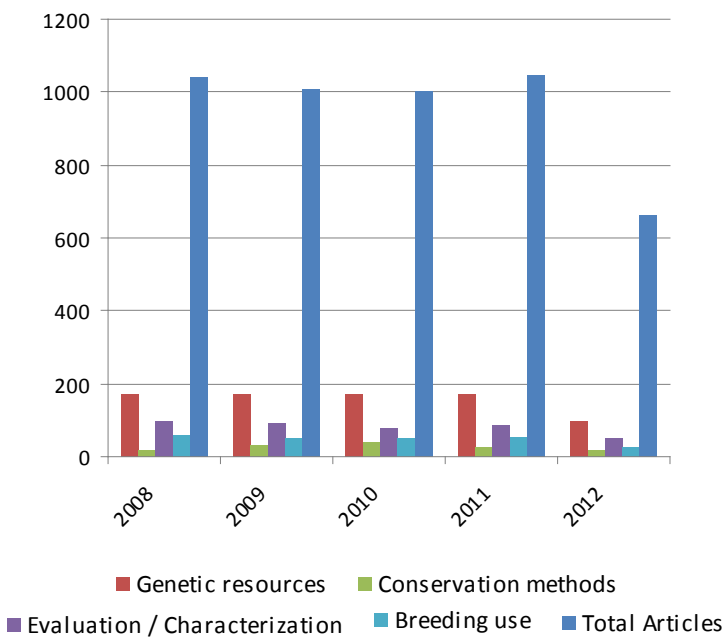

Figure 3. Annual quantity of articles related to plant genetic resources according to the proposed objectives, grouping all journals.
Based on the results, it can be considered that, although the journals evaluated dedicate a space for studies related to PGR, the number of manuscripts focused on this topic could definitely increase. In a way, this should be the likely trend for the coming years, mainly due to the increasing importance of PGR in relation to intellectual property and as an alternative to the search for genes resistant to biotic and abiotic factors to face the expected consequences of $t$ climate change.

Considering the papers which were focused on PGR, it is clear the need for a greater number of studies aimed at improvement and innovation in conservation methods and techniques, which is important for reducing operating costs in germplasm collections and banks. The major weight of studies aimed at the characterization of germplasm was expected due to the amount of unknown accessions and reduced costs of using molecular markers. However, it is necessary to question the real need to characterize all genotypes stored in banks, although the characterization is one of the conditions to promote the use of PGR. Based on the amount of accessions currently stored and on the costs involved in phenotypic and molecular characterization, it is necessary to set priorities for a more effective allocation of the limited financial resources of the collections (Koo and Wright 2008).

\section{Brazilian germplasm collections - a snapshot}

Until the 1940s, the centers of origin of cultivated plants were considered unlimited sources of genetic variability. The expansion of the agricultural frontier without the concern for preserving the environment and natural resources endangered wild relatives of many domesticated species. The possibility of exhaustion of genetic variability of many species and related wild species led the scientific community, in the late 1960 s, to promote the conservation of the hereditary material of many plant species, especially those of agricultural importance, under controlled environmental conditions (Ribeiro 2000). The routine activities of germplasm banks like collection, characterization, evaluation, documentation and conservation of accessions require qualified professionals from various fields of knowledge; these activities present high cost and the return is almost always in long term (Nass 2007). Besides the conservation of genetic variability for future use, another objective is that accessions available are used by their customers.

The first Brazilian germplasm collections were organized in research institutes and universities aiming primarily to support several existing breeding programs. Among them, the contribution of the Instituto Agronômico de Campinas (IAC) in the development of agriculture in São Paulo and in Brazil is indisputable and is due to the research on genetic resources and the creation of active germplasm banks (AGBs) of various plant species, such as coffee, sugarcane, 


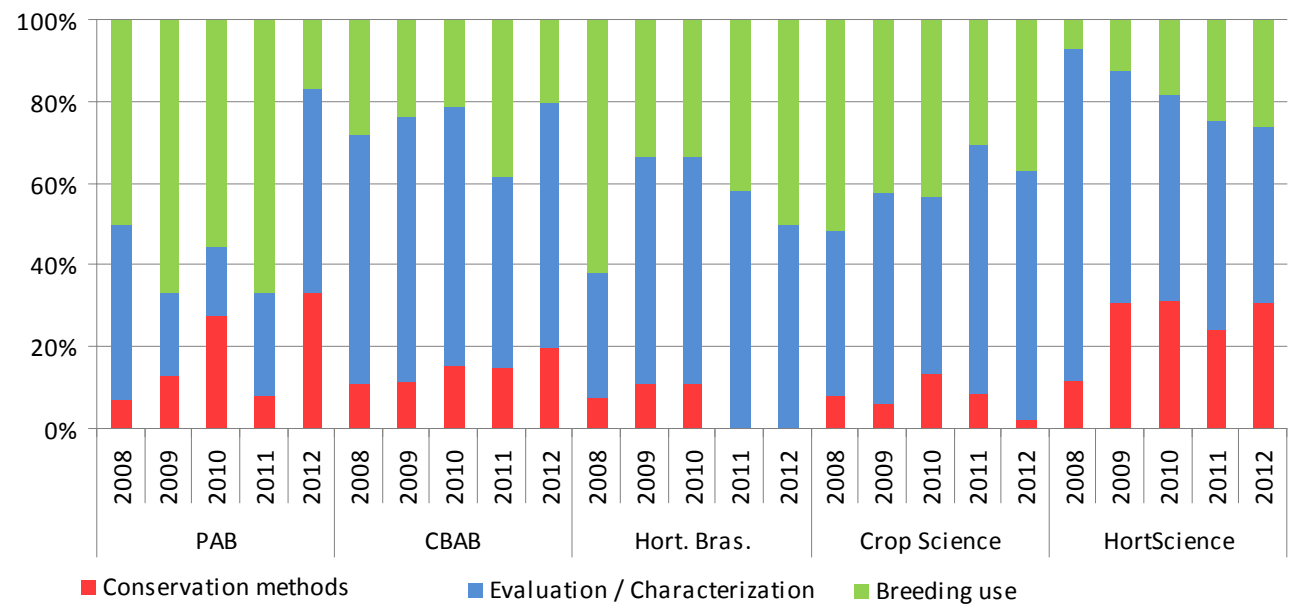

Figure 4. Percentage of articles' objective related to plant genetic resources according to the year and the journal.

rubber, cassava, rice, soybean, common bean, various fruits, vegetables, and ornamental plants. IAC's coffee AGB was established in 1932 at Fazenda Santa Elisa, in Campinas, $\mathrm{SP}$, aiming the research in different areas, including genetic improvement, besides conservation of germplasm.

IAC's coffee AGB (exotic species - example of successful use of the collection in breeding program, with the release of several cultivars important for the development of Brazilian coffee)

IAC's program for genetic improvement started about 80 years ago, and it has released several cultivars, which have been recommended for planting in different regions of the country. It is estimated that $90 \%$ of the Arabica type coffee in Brazil come from cultivars developed at the Institute. The increase of genetic diversity of the collection is a concern of researchers from IAC, and it has had partnership with various institutions in order to establish exchange of coffee germplasm. The short stature cultivars "Catuai Amarelo" and "Catuai Vermelho" have modified systems of coffee production in the country and allowed the introduction of cultivation in large areas of Cerrado in São Paulo, Minas Gerais and Goiás.

Embrapa Vegetables' Capsicum AGB (some autochthonous species - an example of successful use of Capsicum $A G B$ in the breeding program of Embrapa Vegetables)

The Capsicum breeding program led by Embrapa Vegetables started about 30 years ago; it has a collection of more than 4,000 germplasm accessions and large genetic variability. The program involves researchers from different fields and various units of Embrapa, research and educational institutions, cooperatives, producers and processing companies. In the last 20 years lines with resistance to diseases have been made available; also, several cultivars of different types of peppers important for Brazilian agriculture have been released. One of the released cultivars is today responsible for over $50 \%$ of all the pepper sauce produced in the country.
Although the private sector has participated significantly in the development and availability of cultivars and hybrids of corn in the Brazilian market, in the public sector, IAC was one of the pioneer institutions to develop double hybrids in the late 1930's to the 60's (Queiroz and Lopes 2007). The corn breeding program of the Department of Genetics of the Escola Superior de Agricultura "Luiz de Queiroz" (ESALQ/ USP) also made a great contribution, allowing the creation of one of the first corn germplasm collections in the country, in 1952. Research at ESALQ involved both the collection of corn landraces and Brazilian indigenous varieties and the development of cultivars. In 1975, the database was transferred to Embrapa Maize and Sorghum, in Sete Lagoas, Minas Gerais (Andrade et al. 1994). The Department of Genetics of ESALQ also pioneered the establishment of germplasm collections of vegetables, which served as the basis for genetic improvement of various vegetables, with emphasis on onion and brassica programs (Queiroz and Lopes 2007). The Universidade Federal de Viçosa (UFV) was one of the first national institutions to work with soybean breeding. The program started in 1963 and over 20 cultivars have been developed. IAC and Embrapa Soybean began studies with adaptation of soybean cultivars in the 1970s (Borém 2001, Queiroz and Lopes 2007). UFV also keeps some germplasm collections, for example, beans, soy and various vegetables.

The Empresa Pernambucana de Pesquisa Agropecuária (IPA) stood out in the national scenario for developing breeding programs oriented to the Northeast, such as cowpea (Vigna unguiculata), onion and tomato for the industry. Several bean and tomato cultivars were developed and occupied significant acreages due to different traits such as fruit setting at high temperatures, fruit firmness and resistance to several diseases (Queiroz and Lopes 2007), attributes essential for a successful crop in the Northeast. IPA maintains germplasm collections of cowpea (Assunção et al. 2005), sweet potato 
(Ritschel and Huaman 2002), several tropical fruits regionally important like Brazilian cherry (Eugenia uniflora), Brazilian guava (Psidium araça), yellow mombin (Spondias mombin), star fruit (Averrhoa carambola), jackfruit (Artocarpus heterophyllus), soursop (Annona muricata), sugar apple (Annona squamosa), pomegranate (Punica granatum), "umbu" (Spondias tuberosa), guava (Pisidium guajava), sapodilla (Manilkara sapota), among others (Ferreira et al. 2005).

Since 1972, conservation of genetic resources and genetic improvement of cotton, rice, coffee, winter cereals, beans, temperate fruits, cassava, corn and sorghum have been the main lines of research at the Instituto Agronômico do Paraná (IAPAR).

According Valls (2007), the creation of the National Research Center for Genetic Resources (Cenargen, now Embrapa Genetic Resources and Biotechnology), in 1974, by the Empresa Brasileira de Pesquisa Agropecuária (Embrapa), enabled the interaction of this center, with other State and Federal institutions, in order to consolidate the philosophical basis on enrichment and long-term conservation of genetic variability. Such interaction has generated mutual benefits, being it the possibility of establishing a vast network of active germplasm banks (Table 1), or by creating safe conditions for storage of accessions in the long term, under appropriate infrastructure built in Brasília-DF. Currently, the long term collection of Embrapa (Colbase) maintains approximately 120,000 accessions, representing 222 genera and approximately 700 species. It is estimated that, in Brazil, the total number of accessions available in the active germplasm banks is around 300,000.

\section{Using the treasure}

The development of more competitive, better adapted cultivars is a continuous process which requires adaptation to new and often unexpected challenges faced by modern agriculture. Despite the great genetic variability in germplasm collections, underutilization of these resources in genetic breeding programs have been registered in Brazil and other countries, and may have several reasons: practical problems in processing and shipping of samples; legal aspects and quarantine-related issues; lack of information and description of accessions in the banks; restricted adaptability of accessions; insufficient number of breeders to meet the large amount of crops/plant species in the country (even having an available germplasm collection), low seed quality and/or insufficient number of seeds kept in collections; difficulty of crossing exotic germplasm and improved genotypes (Nass 2001, 2011, Valls 2007).

Many plant breeders do not make direct use of the genetic resources since they consider their working collections significant, or because most accessions, despite showing some characteristic of agronomic interest, bring together many undesirable traits that are difficult to manage (linkage drag). However, pre-breeding programs have been shown to be efficient in the use of genetic resources available in AGBs for enlarging the genetic breeding programs of different species (Nass and Paterniani 2000, Nass 2001, 2011, Nass et al. 2007, Nass and Sigrist 2012). The second Brazilian report on the use of genetic resources in Brazil emphasizes several examples of the use of Brazil's collection in prebreeding programs (Mariante et al. 2009).

\section{Economics of conserving plant genetic resources}

The demand for proper valuation of PGR has increased due to new applications offered by biotechnology. Biodiversity held in germplasm banks is the essential raw material for agribusiness and for society in general. When assigning value, one should keep in mind the expected benefit for society. Besides the use related to the production of food, fiber, medicines and bioenergy, the total value of PGR should also consider the cultural, aesthetic and even psychological aspects of the awareness of conserving something that can be extinguished (Brown 1991). But the determination of this value is not trivial, as is determining the cost/benefit of preservation.

Although there is little information about these issues, some studies have sought to reconcile the knowledge of biodiversity with economic principles to enhance and optimize the use and conservation of genetic resources (Evenson and Gollin 2003). For example, given that the budget of germplasm bank is often limited, it is necessary to decide what to conserve. If all accessions in a bank present equal value, accessions with higher maintenance costs would be undesirable. In case all of them have the same cost of conservation, materials which are most likely to be used in the present would be favored. Additionally, similar accessions have less value when compared with rare accessions (Brown 1991, Smale and Koo 2003).

\section{Benefits: Valuation of plant genetic resources}

The total value resulting from the conservation of a particular accession can be categorized into non-use value and use value. Non-use, or existence value, reflects the satisfaction of individuals or societies in simply knowing that something exists and is maintained regardless of use. In turn, use value can be divided into direct and indirect. The indirect use value reflects the contribution of PGR for habitats or ecosystems, while the direct use value is the value generated by the development of food, fiber, biofuels and drugs. Both values have dimensions in the present and in the future. A third value is known by option value, which considers the value in having flexibility of use in relation to 
Table 1. National germplasm collections of some autochthonous and exotic plant species

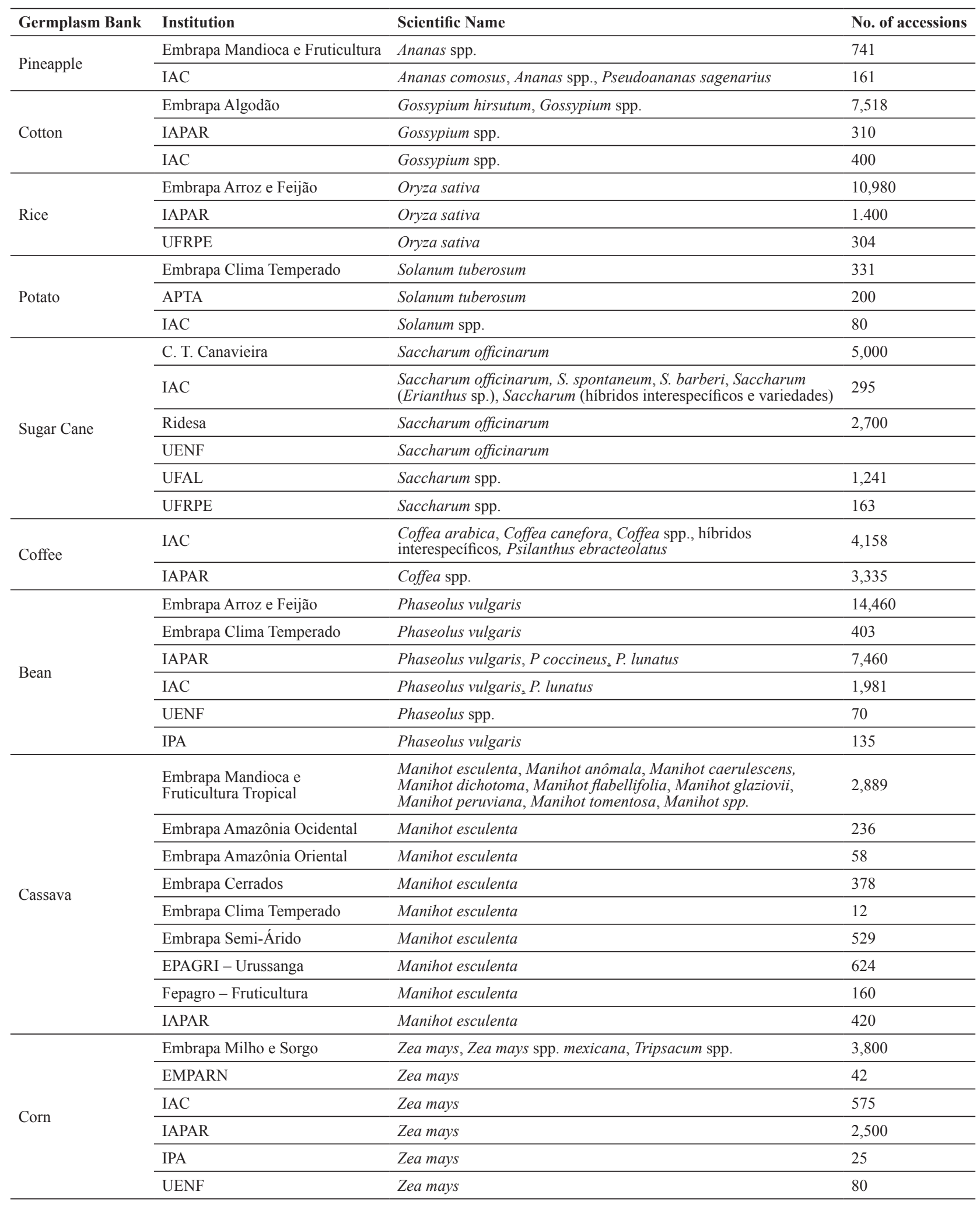




\begin{tabular}{|c|c|c|c|}
\hline \multirow{4}{*}{$\begin{array}{l}\text { Peppers and } \\
\text { Bell Peppers }\end{array}$} & Embrapa Hortaliças & $\begin{array}{l}\text { Capsicum annuum, Capsicum baccatum, Capsicum } \\
\text { chinense, Capsicum frutescens, Capsicum spp. }\end{array}$ & 3,000 \\
\hline & Embrapa Clima Temperado & $\begin{array}{l}\text { Capsicum annuum, Capsicum baccatum, Capsicum } \\
\text { chinense, Capsicum frutescens, Capsicum spp. }\end{array}$ & 347 \\
\hline & UESC & Capsicum spp. & 150 \\
\hline & UFRPE & Capsicum anпиит & 50 \\
\hline \multirow{4}{*}{ Rubber tree } & Embrapa Cerrados & Hevea brasiliensis & 762 \\
\hline & CEPLAC & Hevea spp. & 820 \\
\hline & IAC & Hevea spp. & $1, .000$ \\
\hline & IAPAR & Hevea spp. & 106 \\
\hline \multirow[t]{2}{*}{ Wheat } & IAC & Triticum aestivum, Triticum durum & 6,551 \\
\hline & IAPAR & Triticum aestivum, Triticum durum & 6,619 \\
\hline \multirow{4}{*}{ Grape } & Embrapa Uva e Vinho & Vitis vinifera, Vitis spp. & 1,345 \\
\hline & Embrapa semi-Árido & Vitis spp. & 223 \\
\hline & IAC & Vitis vinifera, Vitis labrusca, Vitis bourquina, híbridos & 360 \\
\hline & UENF & Vitis spp. & 20 \\
\hline
\end{tabular}

Source: Mariante et al. (2009)

a future unexpected demand. Based on these definitions, it is noteworthy the complexity in defining, with confidence, the total value of a single accession or whole germplasm banks. Although the theory for estimating these categories have already been proposed (Brock and Xepapadeas 2003), ultimately, many model parameters may be subjective, especially in relation to non-use, indirect use and option values. This presents a difficulty, since one of the main functions of germplasm banks is to meet future challenges. Therefore, these important components of the total value of a germplasm collection are usually underestimated.

Based on various assumptions, it can be estimated the current value of future benefits of germplasm in breeding by combining the probability of finding a useful accession with its expected benefit (e.g. yield increase). However, the time necessary to explore and incorporate useful genes into agronomically elite materials affects the magnitude of the expected benefits due to the time value of money. Of all the values associated with PGR, the most tangible in practical terms is its direct use, usually measured based on financial gain generated by increased production, improved quality, resistance to biotic and abiotic stresses or other characteristics incorporated into elite materials. These benefits are originated from the use of wild relatives and landraces to introduce desirable traits by breeders, using accessions and information generated by curators of germplasm banks. Estimating the benefits of plant breeding by separating the contribution of breeders to the direct use value of germplasm is a complex task, so most studies aim at estimating the value of genetic improvement as a whole, and not only the use value of genetic resources per se (Rubenstein et al. 2005). In general, the direct increase in productivity achieved with the new variety, for example, can be estimated by multiplying the productivity excess, in relation to a control variety, at market price and quantity sold in a given period. This value is then compared with the total cost of the breeding program for obtaining the variety, resulting in a rate of return. Although these studies present an overview of genetic gain for production, they do not always define correctly the use value and benefits derived from genetic resources. Considering a characteristic controlled by a single gene, the estimate is easily obtained, but there is greater complexity as an increased amount of genes is introduced. Additionally, many of the estimates are based on experimental data, under controlled environmental and management conditions different from those faced by farmers (Alston et al. 1995). Finally, the supply chain and demand in agribusiness is variable, so that a single estimate of gain for the entire agribusiness system is unlikely.

In any case, the results considering the contribution of genetic resources and genetic improvement as a whole emphasize the economic importance of the activity. In most 
cases, the rate of return obtained from plant breeding has been extremely positive, adding value to the entire production chain. Byerlee and Traxler (1995) estimated a rate of return of $52 \%$ in an international cooperation for wheat breeding in developing countries. Pardey et al. (1996) evaluated data from two centers of CGIAR, reporting benefit and cost ratios of 48:1 for rice and 190:1 for wheat. Brennan et al. (1997) suggested that $64 \%$ of the gains from rice breeding in Australia were due to the acquisition of international germplasm, generating benefits of US $\$ 848$ million. Evenson and Gollin (1997) estimated that without the efforts of an international network for evaluation of rice germplasm, 20 new commercial varieties would not have been developed. In this case, the present value of production loss for a period of 20 years would be US\$ 1.9 billion.

Aiming at identifying the intrinsic use value of genetic resources, several empirical approaches have been proposed (see Evenson et al. 1998). However, such methods are poorly used in practice, based on real data. Evenson and Gollin (1997) examined the genealogies of rice varieties produced by IRRI between 1965 and 1990, concluding that the addition of 1,000 accessions to the bank was associated with the obtainment of 5.8 varieties. Assuming a period of 10 years after acquisition and a discount rate of $10 \%$, gains were estimated at US\$ 325 million. Using similar methodology, Lamarié and Evenson (1998) estimated that rice production in India was 5.6\% higher due to the incorporation of landraces in the collection throughout the 1980s.

As seen, the theoretical basis for estimating the total value of genetic resources is still being developed. Since PGRs are considered public goods that are not directly marketed, the biggest limitation is to define a total value for the accessions or genes preserved in a germplasm collection, that considers both use and non-use values.

\section{Costs: The management of collections}

Since quantifying the benefits (products) generated from PGR has shown to be a challenging task, a more effective approach to increase the value of these resources is to correctly manage the costs involved in ex-situ conservation. Cost analysis is derived from microeconomic theory of production, in which a genebank can be treated similarly to any other company (Pardey et al. 2001). Germplasm banks are organized to produce outputs, represented by viable accessions and their information. Based on this simple statement, it is concluded that genebank managers often have to decide about the financial resources needed to produce a certain amount of outputs. As part of the decision process, managers should seek to minimize operational costs using the same infrastructure and maximize production using the same budget. In both cases, the final result will be gain in efficiency.
The total costs of operating a germplasm bank are generally classified into human capital, variables (production labor and operating expenses) and fixed (Koo et al. 2003). The costs involved in the operations of a germplasm bank depend on a number of factors, such as the biological characteristics of the species preserved, preservation methods used, social and economic conditions of the country and local edaphoclimatic factors. Consequently, cost surveys should be performed for each genebank, since conditions and conservation objectives are rarely similar (Koo et al. 2004). For example, the cost of long term conservation of species with vegetative propagation or recalcitrant seeds, which demands special techniques of tissue culture or in vivo conservation, is usually greater than the orthodox seed storage (Smale and Horna 2010).

Despite the difficulties, all germplasm banks share a set of basic activities, which can be summarized to better estimate the components of total operating cost on an annualized basis (Table 2). Variable costs are easier to estimate, since the manager is aware of costs of supplies purchase and employees payment. In turn, the fixed costs can be estimated based on the purchase price of the good, which is depreciated by a determined interest rate (Koo and Smale 2003).

Based on cost information in Table 2, the average cost can be calculated by dividing the total cost by the total number of accessions. For comparison purposes, the mean cost for each activity can also be calculated, or the mean costs of different years of the same activity could be compared to measure the efficiency. For example, the average annual cost of storage is calculated as the total cost of storage in a given year divided by the total number of accessions stored in the collection. The average annual cost can be divided into average variable cost and average fixed cost depending on the components of the total cost considered (Smale and Koo 2003). The mean fixed cost tends to decrease when increasing the number of accessions stored, unless it is necessary to purchase new equipment or expand facilities. Moreover, the average variable cost tends to decrease to a certain quantity of stored material due to efficiency gain (economies of scale). However this cost increases again due to excessive use of variable resources under the same fixed production factors. At this point, managers must make a decision of expanding the facilities or reducing the number of stored accessions. Further clarification on the costs associated with ex-situ conservation is available in a study by Horna and Smale (2010), where costs of conservation of PGR in CGIAR centers were estimated.

Cost analysis has proven to be an essential tool for better management of activities and financial resources spent on the conservation of genetic resources. An inefficient financial 
LL Nass et al.

Table 2. Main costs involved in the activities of germplasm bank (Adapted from Koo and Smale 2003)

\begin{tabular}{|c|c|c|c|c|}
\hline Activity & Human capital & \multicolumn{2}{|c|}{ Variable Costs } & Fixed Costs \\
\hline $\begin{array}{l}\text { Information Management } \\
\text { Data Analysis }\end{array}$ & $\begin{array}{l}\text { IT Manager } \\
\text { Scientist }\end{array}$ & $\begin{array}{l}\text { Data introduction } \\
\text { Equipment Maintenance }\end{array}$ & $\begin{array}{l}\text { Computer supplies Publishing } \\
\text { costs Software license }\end{array}$ & $\begin{array}{l}\text { Server } \\
\text { Computers }\end{array}$ \\
\hline General Management & $\begin{array}{l}\text { Administrative } \\
\text { Manager }\end{array}$ & Secretary & $\begin{array}{l}\text { Office Costs } \\
\text { Electricity } \\
\text { Overhead Costs }\end{array}$ & $\begin{array}{l}\text { Buildings } \\
\text { Other Equipment }\end{array}$ \\
\hline Storage & Curator & $\begin{array}{l}\text { For operation and } \\
\text { maintenance of Cooling } \\
\text { systems and others. }\end{array}$ & Electricity for cooling & $\begin{array}{l}\text { Infrastructure for cold storage } \\
\text { Cooling Systems } \\
\text { Shelves and seed containers }\end{array}$ \\
\hline Viability test & Curator & $\begin{array}{l}\text { Lab Technician } \\
\text { Temporary Workers }\end{array}$ & Chemical reagents and supplies & $\begin{array}{l}\text { Lab equipment and } \\
\text { Infrastructure }\end{array}$ \\
\hline Characterization & $\begin{array}{l}\text { Field Manager } \\
\text { Scientist }\end{array}$ & $\begin{array}{l}\text { Field Workers } \\
\text { Temporary Workers }\end{array}$ & Chemical reagents and supplies & $\begin{array}{l}\text { Data collection equipment and } \\
\text { lab equipment and infrastructure }\end{array}$ \\
\hline Evaluation & $\begin{array}{l}\text { Field Manager } \\
\text { Scientist }\end{array}$ & $\begin{array}{l}\text { Field Technician } \\
\text { Lab Technician }\end{array}$ & Chemical reagents and supplies & $\begin{array}{l}\text { Data collection equipment and } \\
\text { lab equipment and infrastructure }\end{array}$ \\
\hline Pre breeding & $\begin{array}{l}\text { Field Manager } \\
\text { Scientist }\end{array}$ & $\begin{array}{l}\text { Field Technician } \\
\text { Lab Technician }\end{array}$ & Chemical reagents and supplies & $\begin{array}{l}\text { Data collection equipment and } \\
\text { lab equipment and infrastructure }\end{array}$ \\
\hline Dissemination & Curator & $\begin{array}{l}\text { Lab Technician } \\
\text { Temporary Workers }\end{array}$ & $\begin{array}{l}\text { Chemical reagents } \\
\text { Packing Supplies } \\
\text { Shipping Cost }\end{array}$ & $\begin{array}{l}\text { Lab equipment and } \\
\text { infrastructure }\end{array}$ \\
\hline
\end{tabular}

management of collections incurs not only in excessive cost, but also in the incapability of the bank in disseminating feasible accessions containing all the information necessary to meet the demand. Aiming at better management of collections worldwide the System-Wide Genetic Resources Programme (SGRP) of the Consultative Group on International Agricultural Research (CGIAR) has recently developed a database and tools (including a decision-support tool) to assist PGR managers, the Crop GeneBank Knowledge Database (http:// cropgenebank.sgrp.cgiar.org/).

\section{A vision on the future - recommendations for strengthening the area}

Agrobiodiversity has been, since its discovery, one of the pillars of national development. In recent years, the development of national agriculture, both for corporate and family farming, had a great improvement through the adoption of appropriate public policies, higher and more easily accessible credit, continuous and exemplary entrepreneurship of the Brazilian producer, increasing external and internal demand for products traditionally produced in the country, availability of appropriate technologies to tropical agriculture and many other factors. However, the basis of this agriculture has used just a little of our agrobiodiversity and it depends, substantively, on a limited number of species.

An optimistic view of the future:

- Predicts increasing use of agrobiodiversity in favor of Brazilian society and the world's population;

- Predicts the launch of a national program of recovery of germplasm collections of Federal and State public institutions, renewing the seeds and vegetative materials, strengthening the characterization of accessions, and modernizing and integrating the databases so they can be easily accessible to public and private users;

- Predicts the release of a call for proposals, by Federal and State agencies that support research, in a coordinated way, in order to strengthen the capacity of young professionals in national and foreign institutions that have expertise in the subject; 
- Predicts the simplification of legislation, which due to its complexity has tremendously hindered the use of plant genetic resources for the benefit of Brazilian society;

- Continues the strengthening program of Active Germplasm Banks of Embrapa (the largest AGB collection of Brazil), which started with the Agroverde program, in 2010, which supported the AGBs of cassava, cowpea, grape, rice and soybeans;

- Estimates the inclusion of a growing number of plants and their derivatives in the Brazilian diet, which are now forgotten, unknown, unfamiliar, or restricted to specific regions, and makes use of genetic variability to increase the quality of food by the use of traditional techniques and new biotechnology;

- Projects an increase in national and global agriculture production and productivity, based on the rational use of agrobiodiversity and technology, meeting the demand for food, oil, fiber, energy and nutrients of the world's population, and particularly for the less favored ones; and finally,

- Predicts the establishment of ConservaBrasil ${ }^{\circ}$, an audacious and futuristic vision for conservation and use of agrobiodiver- sity. ConservaBrasil ${ }^{\mathscr{O}}$ 's mission is to preserve the long-term national biodiversity, in particular the collections of species of agricultural interest, both native and exotic, for future use for the benefit of Brazilian society; in its vision, ConservaBrasil ${ }^{\circ}$ will have under its tutelage, in 2020, the largest collection of Brazilian germplasm for future use by national agriculture. This initiative will be responsible for keeping thousands of plant, animal and microbial accessions used in Brazil. The germplasm collection maintained by ConservaBrasi ${ }^{\circ}$ will be one of the largest and best preserved in the world. The collection will have captured significant fraction of the genetic diversity of species relevant for Brazilian agriculture. The results of research on long-term conservation of germplasm will enable the Brazilian society to ensure that the varieties, lines, clones, hybrids, semen, ova and microorganisms of interest are being preserved for future use with the highest technical accuracy. Ongoing operations in 2020 will ensure, in the future, the supply of accessions fundamental for maintaining the competitiveness of domestic agriculture. In this process, Brazilian society, with support from Embrapa, will be participant in the efforts of conservation and use of germplasm that will ensure the future of Brazilian agriculture.

\section{Recursos genéticos vegetais: a base de um melhoramento vegetal competitivo e sustentável}

Resumo - Os recursos genéticos vegetais são o combustivel para o melhoramento genético, que na busca por genótipos mais produtivos e adaptados, manipula genes a fim de atender às necessidades dos agricultores e, principalmente, do mercado atual. Entretanto, a utilização dos acessos disponiveis nos bancos de germoplasma é baixa. Os tópicos abordados nesse artigo enfatizam a importância dos recursos genéticos vegetais, alertam para problemas relacionados à vulnerabilidade genética, discutem aspectos de custos envolvidos na conservação e apontam recomendações para o fortalecimento da área no Brasil.

Palavras-chave: Agrobiodiversidade, germoplasma, melhoramento, conservação, custo/beneficio.

\section{REFERENCES}

Alston JM, Norton GW and Pardey PG (1995) Science under scarcity: principles and practice for agricultural research evaluation and priority setting. Cornell University Press, Ithaca, 618p.

Andrade RV, Azevedo JT, Borba CS and Andreoli C (1994) Banco ativo de germoplasma. In Embrapa (ed.) Relatório técnico anual do Centro Nacional de Pesquisa de Milho e Sorgo 1992-1993. Embrapa, Sete Lagoas, p. 276-277.

Assunção IP, M-Filho LR, Resende LV, Barros MCS, Lima GSA, Coelho RSB and Lima JAA (2005) Genes diferentes podem conferir resistência ao Cowpea severe mosaic virus em caupi Fitopatologia Brasileira 30: $274-278$.

Borém A (2001) Melhoramento de plantas. $3^{\text {rd }}$ ed., UFV, Viçosa, $500 \mathrm{p}$.

Brennan J, Singh IP and Lewin LG (1997) Identifying international rice research spillovers in New South Wales. Agricultural Economics 17: $35-44$.
Brock WA and Xepapadeas A (2003) Valuing biodiversity from an economic perspective: a unified economic, ecological and genetic distance approach. American Economic Review 93: 1597-1614.

Brown GM (1991) Valuation of genetic resources. In Orians GH, Brown Jr. GM, Kunin WE and Swierbinski JE (eds.) The preservation and valuation of biological resources. University of Washington Press, Seattle, p. 203-245.

Byerlee D and Traxler G (1995) National and international wheat improvement research in the post green revolution period: evolution and impacts. American Journal of Agricultural Economics 77: 268-278.

Evenson R and Gollin V (1997) Genetic resources, international organizations and improvement in rice varieties. Economic Development and Cultural Change 45: 471-500.

Evenson R and Lemarié S (1998) Optimal collection and search for crop genetic resources. In Smale M (ed.) Farmers, gene banks and crop breeding: economic analyses of diversity in wheat, maize and rice. Kluwer, London, p. 79-82. 
Evenson R, Gollin D and Santaniello V (1998) Agricultural values of plant genetic resources. CABI, Wallingford, 285p.

Ferreira MAJF, Wetzel MMVS and Valois ACC (2005) El estado del arte de los recursos genéticos en las Américas: conservación, caracterización y utilización. Embrapa Recursos Genéticos e Biotecnología e Programa Cooperativo de Investigación y Transferencia de Tecnología para los Trópicos Suramericanos (PROCITROPICOS), Brasília, 100p.

Gollin D and Evenson R (2003) Valuing animal genetic resources: lessons from plant genetic resources. Ecological Economics 45: 353-363.

Goodman MM (1990) Genetic and germplasm stocks worth conserving. Journal of Heredity 81: 11-16.

Horna D and Smale M (2010) Evaluating cost-effectiveness of collection management: a methodological framework. Available at $<$ http://cropgenebank.sgrp.cgiar.org/images/file/management/DST/ framework_dst.pdf $>$ Assessed on Oct 14, 2012.

Koo B and Smale M (2003) Economic costs of genebank operation. In Engels JMM and Visser L (eds.) A guide to effective management of germplasm collections. IPGRI, Rome, p. 93-106 (IPGRI handbooks for genebanks, 6).

Koo B and Wright BD (2008) The optimal timing of evaluation genebank accessions and the effects of biotechnology. American Journal of Agricultural Economics 82: 797-811.

Koo B, Pardey PG, Wright BD, Bramel P, Debouck D, van Dusen ME, Jackson MT, Rao NK, Skovmand B, Taba S and Valkoun J (2004) Saving seeds: the economics of conserving crop genetic resources ex-situ in the future harvest centres of the CGIAR. CABI Publishing, Oxfordshire, p. 7-20.

Koo B, Pardey PG and Wright BD (2003) The economic costs of conserving genetic resources at the CGIAR centres. Agricultural Economics 29: 287-297.

Mariante AS, Sampaio MJA and Inglis MCV (2009) The state of Brazil's plant genetic resources. Embrapa Technological Information, Brasília, $163 \mathrm{p}$.

MMA (2011) Quarto relatório nacional para a convenção sobre diversidade biológica: Brasil/Ministério do Meio Ambiente. MMA, Brasília, 248p.

Nass LL (2001) Utilização de recursos genéticos vegetais no melhoramento. In Nass LL, Valois ACC, Melo IS and Valadares-Inglis MC (eds.) Recursos genéticos e melhoramento: plantas. Fundação MT, Rondonópolis, p. 30-55.

Nass LL (2007) Recursos genéticos vegetais. Embrapa Recursos Genéticos e Biotecnologia, Brasília, 858p.

Nass LL (2011) Pré-melhoramento vegetal. In Lopes MA, Fávero AP, Ferreira MAJF, Faleiro FG, Folle SM and Guimarães EP (eds.) Prémelhoramento de plantas; estado da arte e experiências de sucesso. Embrapa Informação Tecnológica, Brasília, p. 23-38.
Nass LL and Paterniani E (2000) Breeding: a link between genetic resources and maize breeding. Scientia Agricola 57: 581-587.

Nass LL and Sigrist MS (2012) Wild species: potential use in prebreeding. In Borén A, Lopes MTG, Clement CR and Noda H (eds.) Domestication and breeding: amazon species. Suprema, Viçosa, p. 101-115.

Nass LL, Nishikawa MAN, Fávero AP and Lopes MA (2007) Prémelhoramento de germoplasma vegetal. In: Nass LL (ed.) Recursos genéticos vegetais. Embrapa Recursos Genéticos e Biotecnologia, Brasília, p. 683-744.

Pardey PG, Alston JM, Christian JE and Fan S (1996) Hidden harvest: U.S. benefits from International Research Aid. International Food Policy Research Institute, Washington, 17p.

Pardey PG, Bonwoo Koo, Wright BD, Van Dusen ME, Skovmand B and Taba S (2001) Costing the conservation of genetic resources: CIMMYT's ex situ maize and wheat collection. Crop Science 41: 1286-1299.

Queiroz MA and Lopes MA (2007) Importância dos recursos genéticos vegetais para o agronegócio. In Nass LL (ed.) Recursos genéticos vegetais. Embrapa Recursos Genéticos e Biotecnologia, Brasília, p. 61-119.

Reifschneider FJB, Henz GP, Ragassi CF, Anjos UG and Ferraz RM (2010) Novos ângulos da história da agricultura no Brasil. Embrapa Informação Tecnológica, Brasília, 112p.

Ribeiro CSC (2000) Criando novas variedades. In Reifschneider FJB (org.) Capsicum: pimentas e pimentões no Brasil. Embrapa Transferência de Tecnologia/Embrapa Hortaliças, Brasília, p. 68-80.

Ritschel PS and Huamán Z (2002) Variabilidade morfológica da coleção de germoplasma de batata-doce da Embrapa-Centro Nacional de Pesquisa de Hortaliças. Pesquisa Agropecuária Brasileira 37: 485-492.

Rubenstein KD, Heisey P, Shoemaker R, Sullivan J and Frisvold G (2005) Crop genetic resources: an economic appraisal. USDA, Washington, 41p. (Economic Information Bulletin, 2).

Silva JAA, Nobre AD, Manzatto CV, Joly CA, Rodrigues RR, Skorupa LA, Nobre C, Ahrens S, May PH, Sá TDA, Cunha MC and Rech Filho EI (2011) O código florestal e a ciência: contribuições para o diálogo. Sociedade Brasileira para o Progresso da Ciência, São Paulo, 124p.

Smale M and Koo B (2003) Biotechnology and genetic resource policies: what is a genebank worth? International Food Policy Research Institute (IFPRI), Brief 7: 1-5.

Sousa GS (1879) Tratado descriptivo do Brazil em 1587. $2^{\text {nd }}$ ed., João Ignácio da Silva, Rio de Janeiro, 382p.

Valls JFM (2007) Caracterização de recursos genéticos vegetais. In Nass LL (ed.) Recursos genéticos vegetais. Embrapa Recursos Genéticos e Biotecnologia, Brasília, p. 281-342. 